\title{
Damage caused by the small red-belted clearwing borer (Synanthedon myopaeformis Borkhausen) in cultivars grafted on different types of rootstocks
}

\author{
Barbara NÉMETHNÉ MAJOR, Rita LEDÓNÉ ÁBRAHÁM, \\ Erzsébet ENZSÖL, Gábor JENSER ${ }^{\dagger}$ \\ Faculty of Agricultural and Food Sciences, \\ Széchenyi István University, \\ 9200 Mosonmagyaróvár, Vár 2, Hungary \\ e-mail: nemeth-major@hotmail.com (corresponding author); \\ abraham.rita@sze.hu; enzsol.erzsebet@sze.hu
}

Manuscript received January 30, 2017; revised February 28, 2017; accepted March 3, 2017

\begin{abstract}
Considerable damage caused by the red-belted clearwing was observed in the biologically controlled apple orchard. In all cases, the larvae were found in the tumourlike tissue proliferations developing at the grafting point of the rootstock (M9) and scion, while no larva was found in crowns and cut surfaces. Samplings involving different cultivars were implemented in two apple orchards; in Bösárkány, where trees are grafted on M9 rootstocks and tumours were found at grafting points, and in Mosonmagyaróvár, where trees are grafted on M26 rootstocks and no proliferations were found at graft unions. During the aforementioned samplings, the numbers of larvae living in the tissue proliferations were counted, the sizes of tumours were measured, and the flight dynamic of adult clearwings was investigated. Research results reveal that damage caused by the clearwing larvae was only observed in trunks with tumour-like disorders (Bösárkány), where feeding larvae were found in $15.3 \%$ of the examined trunks in cultivar Royal Gala, $4.6 \%$ in Idared, $2.6 \%$ in Jonagold, and $1.3 \%$ in Florina. We investigated whether there is a correlation between the size of tumours and the degree of damage. The highest rate of proliferations was found on cultivar Florina, where only a minimum degree of damage was experienced. The lowest rate of proliferations was observed on cultivar Gala, which suffered the highest degree of damage done by clearwing larvae.

According to sex-pheromone trap catches, the flight period of male clearwings occurred simultaneously in both studied orchards from mid-May to mid-August. On the basis of scent trap catch results, however, it has to be highlighted that females were only present at the Bösárkány research site.
\end{abstract}


It is assumed that the absence of females in the Mosonmagyaróvár orchard can be attributed to the fact that they did not find such suitable oviposition sites as tissue proliferations. Hence, egg-laying and damage caused by the larvae did not happen there either.

Keywords: apple clearwing moth, rootstock-scion incompatibility, tissue proliferation, apple cultivars, flight dynamic

\section{Introduction}

The red-belted clearwing (Synanthedon myopaeformis Borkhausen) has not been regarded a pest of apple trees for a long period of time. Its occurrence is not mentioned in the works of Jablonowski [1, 2], Jenser [3], Bognár and Huzián [4]. Reichart [in Ubrizsy and Reichart 5] argues that its caterpillar feeds under the barks of trees weakened by illnesses or frost damages. Balás [6] points out that welltreated and healthy trees with intact bark are not exposed to damages caused by this pest. Its presence, and especially the rapid increase of its population, will only have to be reckoned with in trees with tumour-like disorders and injured barks. They both considered this species a secondary pest of apple trees.

Considerable damage caused by the red-belted clearwing in well-treated orchards was first observed in the 1970s in intensive orchards located in the region between the Danube and Tisza rivers [7, 8]. Chrestian and Lavy [9] reported damages done by the clearwing in France, which occurred on seemingly "healthy" trees. The common feature of the damages in France and in Hungary is that in both countries the high abundance of the clearwing moth was observed in regularly pruned but otherwise intact, healthy trees [10]. According to Balázs et al. [11], the rapid increase of the clearwing population and the occasionally large damage can be attributed to changes in apple production technology.

It has to be considered that apple orchards in their "modern" sense were first established in Hungary in the middle of the 1930s. Those plantations consisted of vigorously growing trees with medium-sized trunks, which were moderately pruned in the cropping phase and their barks were usually smooth.

From the end of the 1950s, mostly in orchards where trees were grafted on semi-vigorous M4 rootstocks and pruned in the form of the production arm spindle crown shape, as a result of intensive pruning, the trees have suffered a lot of cut injuries. Due to the lack of its natural enemies, the $S$. myopaeformis population increased rapidly, causing considerable damage in apple orchards. Ilovai and Szabó [12] claim that any factor that injures the bark (cut surface, hail, frost, etc.) will significantly contribute to the growth of the pest's population.

Since the 1980s - in favour of the dwarfing effect -, the dwarfing M9 has been the most widely used rootstock; its rate of propagation has increased nearly 
up to $50 \%$ during the last ten years. The main reason for its popularity is that this rootstock is perfectly suited to establishing high-density orchards. Apple trees grafted on M9 rootstocks begin producing fruit within a short period of time, their fruits grow bigger, and generally they can be harvested one week earlier than those grafted on M4 rootstocks. However, their disadvantages are that they require a support system (cordon) as well as intensive pruning and regular watering. The wound callus developing on the edge of the often 2-4-cm diameter cut surfaces caused by intensive pruning provides suitable conditions and environment for the egg-laying of $S$. myopaeformis and for the development of the larvae. Ateyyat and Al-Antary (2006) in Jordan concluded that out of the rootstocks M9, M26, and M106, the latter one proved to be the most resistant to the damage caused by the red-belted clearwing since the lowest number of eggs and larvae were found there.

In recent years, an additional factor has facilitated the growth of the pest's population. In order to create new crown forms and dwarf trees that correspond to current production requirements and to enhance the dwarfing effect, budding has been carried out at about $15-20 \mathrm{~cm}$ above the soil surface, which is different from the earlier practice. In the case of rootstock-scion incompatibility, a block of nutritive substances develops in the unit between the grafting point and the root collar, which proves to be appropriate for the insect's oviposition and the development of the caterpillars [14]. This damage might lead to the death of the host tree. One has to agree with Jenser [15], who suggested that views about the economic impact of the red-belted clearwing have to be modified on the basis of experience obtained in recent years.

Our samplings conducted in two different apple orchards provided an appropriate opportunity to investigate the question: to what extent will the rootstock-scion incompatibility lead to damage caused by the red-belted clearwing?

\section{Materials and method}

Data for analysis was taken within simultaneous samplings implemented in two different orchards used as research sites; one of them located in Mosonmagyaróvár, while the other one in the outskirts of Bösárkány, which is a small town near Mosonmagyaróvár. The studied orchard in Bösárkány is a biologically controlled plantation. It is a nearly one-hectare family-owned orchard, which was established in 1997, and since 2009 production has been carried out as biologically controlled. The main types of cultivars include Royal Gala, Idared, Florina, Pinova, and Jonagold, all grafted on M9 rootstocks. A remarkably big tissue proliferation can be found at grafting points on the three studied cultivars (Gala, Idared, and Florina). Pest control - primarily against the codling moth - is carried out by 
applying two substances: Dipel, which contains Bt toxin, and Madex, which contains granulosis virus.

The control evaluations were implemented in a 1,200 $\mathrm{m}^{2}$ control area, which is the property of Széchenyi István University - Faculty of Agriculture and Food Sciences, Mosonmagyaróvár. This orchard does not receive any plant protection treatment at all. 18 different types of cultivars can be found there, of which the following five were studied during our research: Florina (M9 rootstock), Gala Must (M26 rootstock), Idared (M9 rootstock), Jonagold Wilmuta (M9 rootstock), and Golden B (M26 rootstock). Regarding the aforementioned cultivars, no tissue proliferations can be found at grafting points. It is important to mention that the orchard has not been cultivated on a regular basis for years; spring pruning was carried out in 2012; however, in 2013, not even that was performed. In the orchard, no pesticides or any plant health treatment are employed at all.

As for the methods, three different types of data-collecting instruments were employed in the form of samplings: examining the damage caused by the larvae per cultivar; measuring the size of tumours and counting the number of larvae in them per cultivar; observing the flight dynamic of clearwing adults and the change in the number of adults.

Samplings targeting to examine the damage caused by clearwing larvae were conducted on three occasions in 2012: on $23^{\text {rd }}$ April, on $5^{\text {th }}$ June, and on $20^{\text {th }}$ September at both research sites, involving four cultivars: Royal Gala, Florina, Idared, and Jonagold. 50 trunks per cultivar were examined. Data concerning the number of damaged trees and the exact location of the damage was recorded.

In the Bösárkány orchard, the larvae were found in the proliferative disorders developing near the root collar. Hence, in order to study whether there is a correlation between the size of tumours and the degree of damage, we measured the diameter of tumours and the diameter of trunks for each cultivar at a height of $50 \mathrm{~cm}$ of the trunk above soil surface. 50 trunks per cultivar were examined on 3 November 2014.

The flight dynamic of red-belted adult clearwings was monitored by means of trapping. Three different types of lures were located inside both orchards:

- Sex pheromone traps: 5 pieces of "Csalomon"-type traps were placed at both experimental plots, and they were functioning from 25 April to 1 September; catches were controlled every other day.

- Scent traps: a home-made mash of apples cut into small pieces, yeast, apple juice, and beer was prepared. The fermented mixture was put in plastic bottles, which were cut in half and suspended on trees. 5 traps were located inside each research site, which were controlled every other day.

- Pear-ester traps: these traps were received from the Plant Protection Institute Centre for Agricultural Research for experimental purposes. We were to study its efficacy and to compare and contrast the number of catches with those of 
the sex pheromone and apple mash trap catches. 5 traps were employed as well, which were controlled every other day.

Statistical analyses were performed by using the software program Statistica (version 11; StatSoft, Inc. 1984-2012). A hypothesis analysis was performed involving three cultivars (Gala, Idared, and Florina) in order to justify whether the circumference ratio of tumours and trunks significantly differ from each other (ttest). The tendency of male catches in pheromone traps at both research sites was analysed by applying a quadratic trend function $[16,17]$.

\section{Results and discussions}

\section{Damage caused by S. myopaeformis larvae}

Research findings indicate that at the Bősárkány research site a total number of $36 \mathrm{~S}$. myopaeformis larvae were found in the examined 600 trunks during three samplings conducted in April, June, and September. This figure reveals a 6\% damage rate on average. The highest number of larvae was observed in June (21 pieces), which covered 58\% of the total annual samplings. The recorded larvae number regarding each cultivar is presented in Table 1 . We experienced a striking damage in cultivar Royal Gala, where feeding larvae were found in $15.3 \%$ of the studied tree trunks. In addition, 64\% of the total larvae number was found in the aforementioned cultivar, which specimens were even present during the September sampling. Regarding the other three cultivars, the clearwing larvae damaged $4.6 \%$ of the trunks in cultivar Idared, 2.6\% in cultivar Jonagold, while in cultivar Florina only a minimum of $1.3 \%$ damage was observed.

As for the exact place of damage, it has to be highlighted that larvae were only found in the tumour-like tissue proliferations developing at grafting points M9 rootstock in Bősárkány -, whereas no larvae were found in crowns or in cut surfaces. Consequently, damage always occurred 10-20 cm above the root collar at graft unions. Among the studied cultivars, Royal Gala was found to suffer the most damage. It can be argued that the high degree of damage was facilitated by the fact that an inappropriate rootstock (M9) was chosen to the scion within the grafting process, which are not compatible with each other. Besides, budding was carried out rather high; so, it can be suggested that the loose-textured tumour developing at the grafting point is highly accessible and suitable for the females' oviposition and later for the development of the larvae, as it was also experienced by Balázs and Khanh [14]. 
Table 1. Damage caused by clearwing larvae and tissue proliferation sizes per cultivar in the Bősárkány orchard

\begin{tabular}{|l|l|c|c|c|c|}
\hline \multicolumn{1}{|c|}{ Bösárkány } & \multicolumn{1}{|c|}{ Date of sampling } & Gala & Idared & Jonagold & Florina \\
\hline \multirow{3}{*}{$\begin{array}{l}\text { Number of damaged trunks } \\
\text { (pieces/50 trunks) }\end{array}$} & 23 April 2012 & 0 & 5 & 0 & 0 \\
\cline { 2 - 6 } & 5 June 2012 & 13 & 2 & 4 & 2 \\
\cline { 2 - 6 } & 20 September 2012 & 10 & 0 & 0 & 0 \\
\hline $\begin{array}{l}\text { Total number of damaged trunks } \\
\text { (pieces/150 trunks) }\end{array}$ & 23 & 7 & 4 & 2 \\
\hline Ratio of damaged trunks (\%) & $\mathbf{1 5 . 3}$ & $\mathbf{4 . 6}$ & $\mathbf{2 . 6}$ & $\mathbf{1 . 3}$ \\
\hline Mean diameter of damaged tumours (cm) & 35.97 & 36.67 & No data & 38.57 \\
\hline Mean diameter of healthy tumours (cm) & 33.97 & 34.90 & No data & 37.57 \\
\hline Mean circumference of damaged trunks (cm) & 17.27 & 15.07 & No data & 14.77 \\
\hline Mean diameter of healthy trunks (cm) & 16.43 & 16.43 & No data & 13.73 \\
\hline
\end{tabular}

The size of tumours and the number of larvae

We measured the circumferences of tumours and the circumferences of trunks at a height of $50 \mathrm{~cm}$ of the trunk above soil surface, and their ratio were compared for each cultivar (Figure 1).

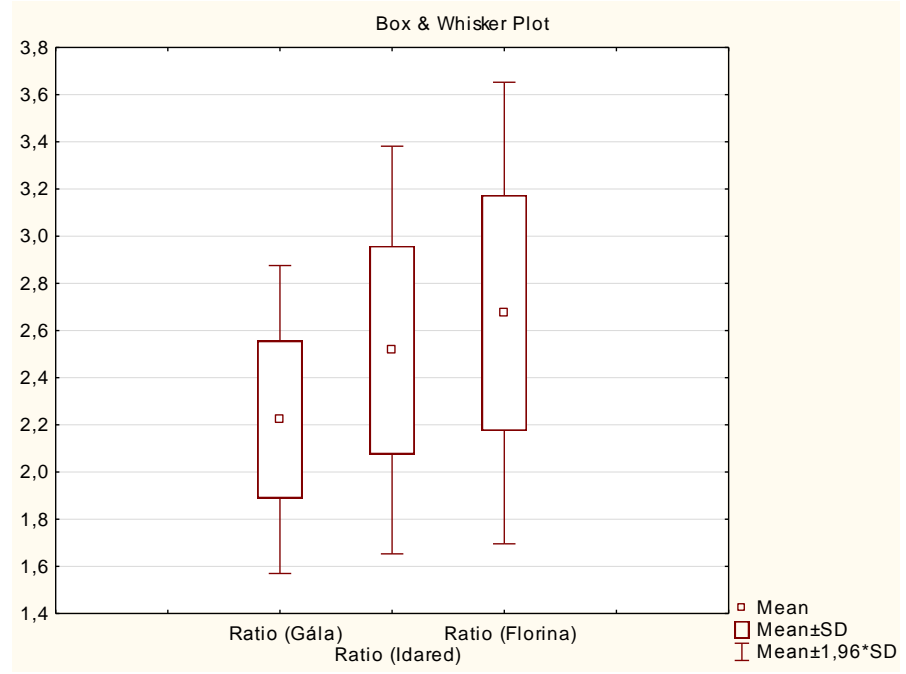

Figure 1. Tumour circumference and trunk circumference ratio of different cultivars (Gála, Idared, Florina) 
As Table 2 shows, the highest rate of tissue proliferation was observed on cultivar Florina, where the circumferences of tumours were 2.7 times the circumferences of trunks. The lowest degree of proliferation was observed on cultivar Gala, where the circumferences of tumours were 2.2 times the circumferences of trunks.

Table 2. Damaged tumour circumference and trunk circumference ratio per cultivar. Descriptive statistics (valid number, mean, minimum, maximum, standard deviation)

\begin{tabular}{lccccc}
\hline \multicolumn{5}{c}{ Descriptive Statistics } \\
\hline Variable & Valid N & Mean & Minimum & Maximum & Std. Dev. \\
Ratio (Gála) & 30 & 2.2 & 1.4 & 2.9 & 0.33 \\
Ratio (Idared) & 30 & 2.5 & 1.7 & 3.5 & 0.44 \\
Ratio (Florina) & 30 & 2.7 & 1.2 & 3.7 & 0.50 \\
\hline
\end{tabular}

A hypothesis analysis was performed in order to justify that the ratio per cultivar does not differ with a 95\% probability (null hypothesis). The result of the paired t-test reveals that the mean values of ratio only equal statistically when comparing the cultivars Idared and Florina $(p=0.2017, p>0.05)$. When comparing cultivar Gala to those in the other two cases, mean values differ from each other significantly $(\mathrm{p}=0.005$ and $0.0001, \mathrm{p}<0.05)$.

The low ratio experienced in cultivar Gala differs significantly; however, it is lower than those experienced in the other two cultivars, as it is also confirmed by the statistical analyses presented in Table 3.

Thus, our hypothesis assuming that the extent of damage is higher in a bigger tissue proliferation has not been proved. On the contrary, damage reached its highest level in cultivar Gala, which showed the lowest ratio of tissue proliferation.

It is interesting to note that no larvae or any damage related to the red-belted clearwing were found at the abandoned control site, neither at cut surfaces nor at root collars regardless of the type of cultivar. It is true, however, that no tissue proliferations were found at grafting points; here, cultivar Gala was grafted on M26 rootstock.

\section{Changes in the number of adult clearwings}

Parallel to the evaluations targeting to investigate the damage caused by clearwing larvae, we also studied the changes in the number of adults at both research sites.

The sex pheromone traps caught a great number of flying males at both experimental plots; in the biologically controlled orchard, a total number of 296, while in the control Mosonmagyaróvár orchard a total number of 365 specimens were trapped (Table 4). 


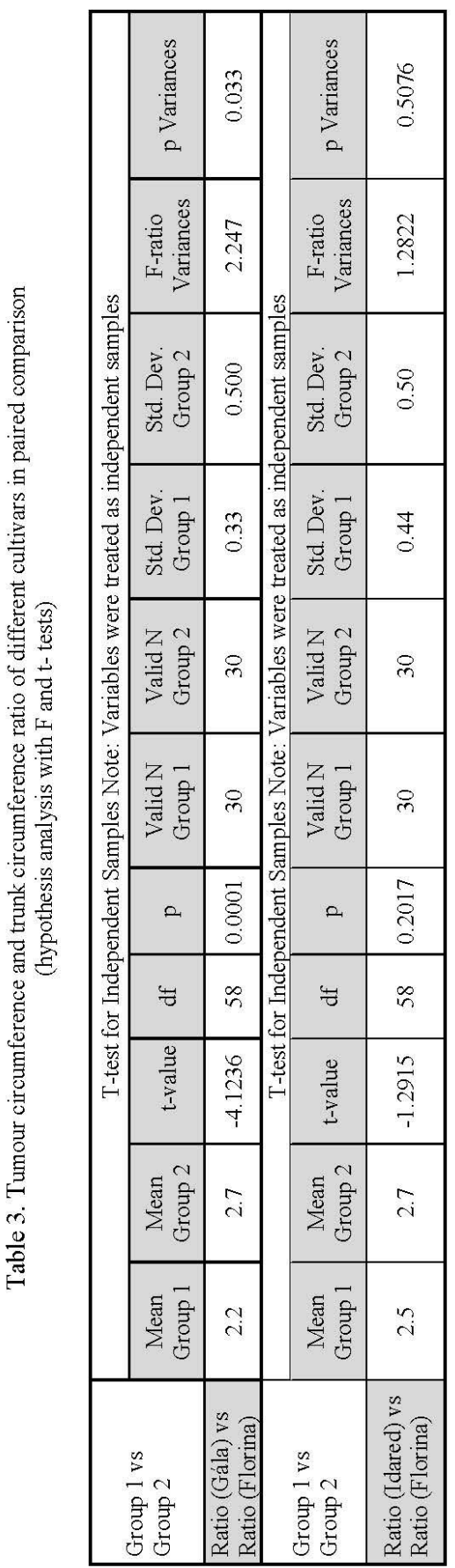


Figure 2 presents the flight dynamic curves created on the basis of catch results obtained at the research sites. The en masse occurrence of flying males was observed in June/July, when both experimental plots yielded more than 15 catches/2 days. The highest catches were recorded on $9^{\text {th }}$ July in the biologically controlled orchard with a total number of 38 captured specimens/ 2 days, while at the control site peak numbers were counted on $20^{\text {th }}$ June, when 68 adults flew into the traps. The last male adults were trapped on $14^{\text {th }}$ August. It can be argued that swarming happened simultaneously at both research sites, as it is also confirmed by the statistical analysis (Figure 3).

After indicating the number of trapped male adults on the same graph, we installed quadratic curves through the obtained points. Calculating the maximum places from their equation, the researchers arrived to the conclusion that the maximum of swarming happened approximately on the $181^{\text {st }}$ day of the year $\left(29^{\text {th }}\right.$ July) in the biologically controlled orchard and on the $176^{\text {th }}$ day of the year $\left(24^{\text {th }}\right.$ July) in the abandoned orchard.

The flight dynamic curves justify the existence of a prolonged flight period of the red-belted clearwing, which corresponds to what Le Duc Khanh et al. [18] also suggest.

Table 4. Numbers of adults caught in different types of traps in Bösárkány and in Mosonmagyaróvár

\begin{tabular}{lcccccc}
\hline $\begin{array}{l}\text { Types of cultivars in } \\
\text { Bösárkány bio-orchard }\end{array}$ & Gala & Idared & Jonagold & Florina & Pinova & all \\
\hline $\begin{array}{l}\text { Pheromone trap catches } \\
\text { (pieces/ year) }\end{array}$ & 85 & 60 & 66 & 30 & 55 & 296 \\
$\begin{array}{l}\text { Scent trap catches } \\
\text { (pieces/year) }\end{array}$ & 17 & 11 & 12 & 13 & 9 & 62 \\
$\begin{array}{l}\text { Pear-ester trap catches } \\
\text { (pieces/year) }\end{array}$ & 8 & 5 & 6 & 6 & 3 & 28 \\
\hline $\begin{array}{l}\text { Types of cultivars in } \\
\text { Mosonmagyaróvár } \\
\text { control orchard }\end{array}$ & Gala & Idared & Jonagold & Florina & Golden & all \\
$\begin{array}{l}\text { Pheromone trap catches } \\
\text { (pieces/year) }\end{array}$ & 76 & 83 & 81 & 65 & 60 & 365 \\
$\begin{array}{l}\text { Scent trap catches } \\
\text { (pieces/year) }\end{array}$ & 0 & 1 & 0 & 0 & 0 & 1 \\
$\begin{array}{l}\text { Pear-ester trap catches } \\
\text { (pieces/year) }\end{array}$ & 0 & 0 & 0 & 1 & 0 & 1 \\
\hline
\end{tabular}




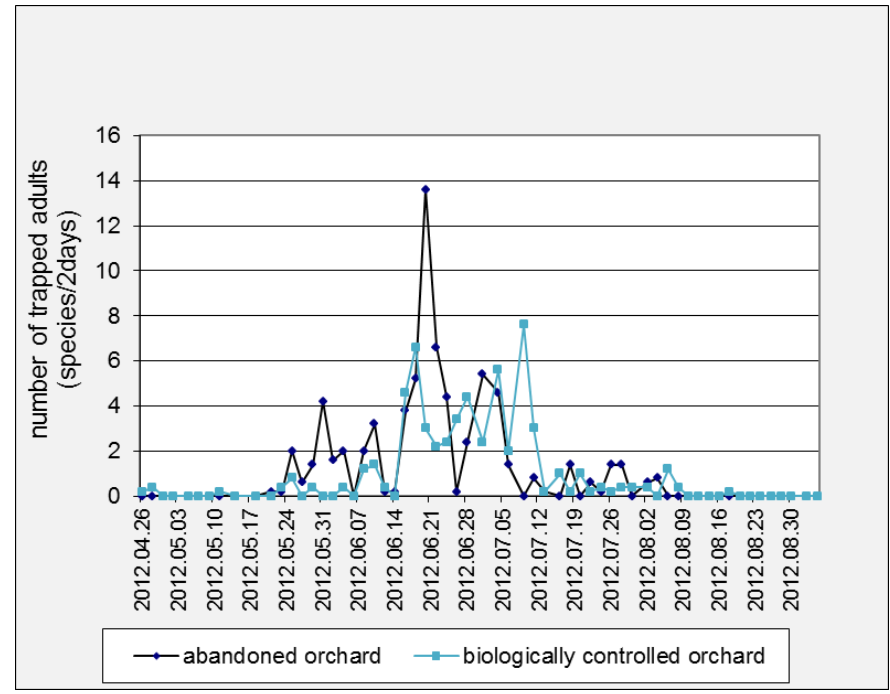

Figure 2. Changes in the number of S. myopaeformis males based on sex pheromone trap catches

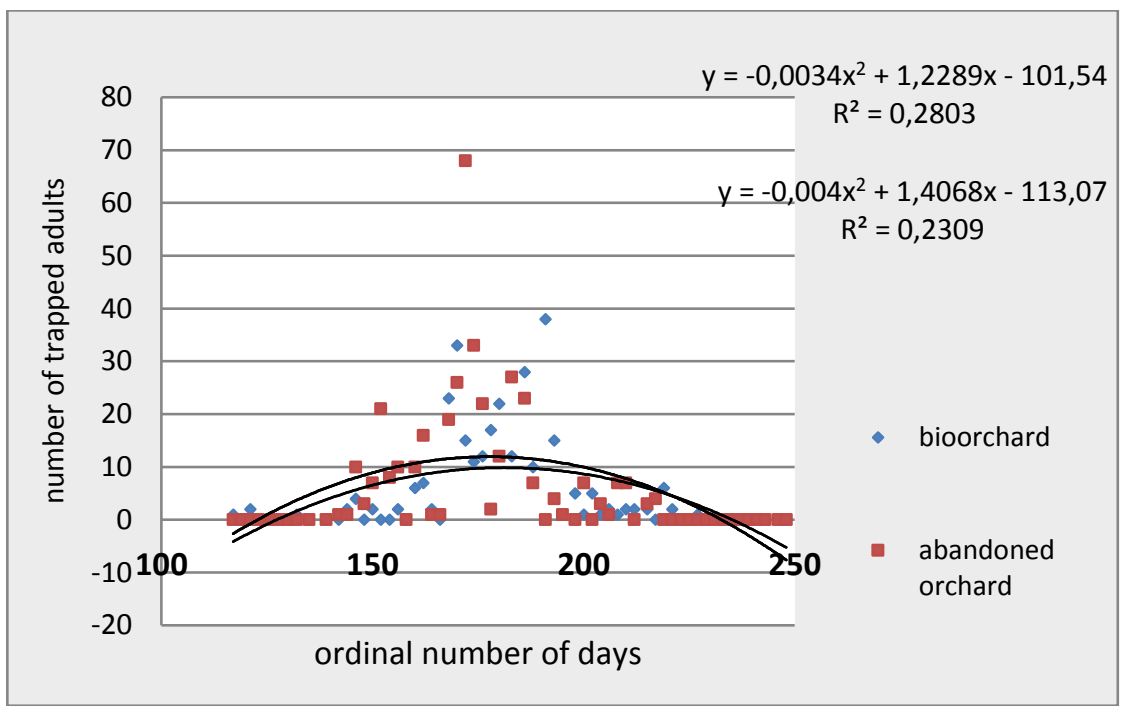

Figure 3. Flight curves based on sex pheromone trap catches

The reason why the red-belted clearwing is attracted to apple-juice-baited traps and fermenting fruit mashes is that this species requires maturation nutrition. Apple-juice-baited scent traps successfully attract flying moths, and therefore their 
flight dynamic can also be monitored. Both males and females are attracted to traps of this nature $[19,20]$.

The numbers of adults caught in scent traps are totally different at the two research sites. In the biologically controlled orchard, a total number of 62 adults were trapped between $16^{\text {th }}$ June and $26^{\text {th }}$ July, while at the control site only 1 specimen was found in the lures. Consequently, according to mash trap catch results, there was no flight to be recorded at the control research site, which indicates the total absence of female clearwings in the area. That might be the reason why no mating, egg-laying, and damage occured in the Mosonmagyaróvár control orchard. Nevertheless, the presence of males is justified by the continuous male catches in the sex pheromone traps. The question arises whether the reason for the lack of damage at the control site is the total absence of females, or the insects were present but could not find suitable places, that is injured surfaces for egg-laying since pruning was neglected in the orchard and no proliferations were experienced at grafting points.

The third type of lure we employed was the pear-ester trap, which attracts both male and female clearwing adults; however, it cannot be considered the most effective attractant of this species; in the biologically controlled orchard, only 28 adults were caught in the whole vegetation, while in the control orchard only one specimen was trapped (Table 4). The catch results of pear-ester traps confirm - in line with that of the scent traps - that no female moths were present in the control orchard.

Regarding pheromone and scent trap catches per cultivar (Table 4), the highest number of $S$. myopaeformis adults was collected in cultivar Gala in the Bősárkány orchard; $28.7 \%$ of the flying males and $27.4 \%$ of the total scent trap catches were found in Gala out of the 5 examined cultivars. Similarly, the largest damage was also observed in cultivar Gala, as it is presented in Table 1. In the control orchard, no remarkable difference in the number of trapped adults was observed among the different cultivars; however, only males were present there, and no damage caused by clearwing larvae was experienced.

\section{Conclusions}

Considerable damage caused by the red-belted clearwing larvae was experienced in those orchards where loose-textured tissue proliferations developed on the root collars of trees, which prove to be suitable for the egg-laying of females and provide excellent living conditions for the development of the larvae. Consequently, not only the existence of wound calluses caused by intensive pruning will increase the danger of larvae occurrence, but inappropriate rootstock choice and inadequate budding can also lead to damages, and at worse to the death 
of the host tree. It can be suggested that appropriate cultivar selection might also play an important role in preventing damages caused by clearwing larvae. Cultivar Gala was found to be rather susceptible. Conducting larvae control and management is especially difficult in biologically controlled orchards because of the larvae's "hidden" life and the prohibition of applying pesticides. Further research should be carried out to investigate which methods and techniques - apart from wound treatment right after pruning - could be applied in biologically controlled orchards to prevent the egg-laying of females. Such techniques as treating the trunks with substances containing oil, applying lime, or possibly taking advantage of the repellent effect of the powder made from fallen red-belted clearwings prove promising.

\section{References}

[1] Jablonowski, J. (1912), A gyümölcsfák és a szőlő kártevő rovarai. Pallas Részvénytársaság Könyvsajtója, Budapest.

[2] Jablonowski, J. (1913), A gyümölcsfák védelme az élésködők ellen. „Pátria” Irodalmi Vállalat és nyomdai Rt., Budapest.

[3] Jenser, G. (1969), Üzemi gyümölcsösök növényvédelme (alma és csonthéjas termésüek). Mezőgazdasági Kiadó, Budapest.

[4] Bognár, S., Huzián, L. (1974), Növényvédelmi állattan. Mezőgazdasági Kiadó, Budapest.

[5] Ubrizsy G., Reichart, G. (1958), Termesztett növényeink védelme. Mezőgazdasági Kiadó, Budapest.

[6] Balás, G. (1963), Kertészeti növények állati kártevői. Mezőgazdasági Kiadó, Budapest.

[7] Mikulás, J. (1973), Adatok a Synanthedon myopaeformis Borkh. előfordulásáról üzemi gyümölcsösben. Növényvédelem 9, 21-22.

[8] Balázs, K. Vajna, L. (1971), Bogyós gyümölcsüek védelme. Mezőgazda Kiadó, Budapest.

[9] Chrestian, P., Lavy, J. (1966), Troisiéme année d'étude de la sesie du pommier dans le Languedoc. Phytoma 178, 27-32.

[10] Mészáros, Z., Reichart, G. (1993), Lepkék - Lepidoptera. In: Jermy, T., Balázs, K. (eds), A növényvédelmi állattan kézikönyve 4/A. Akadémiai Kiadó, Budapest, 17.

[11] Balázs, K., Le Duc, Khanh, Farkas, K. (1995), Az üvegszárnyú almafalepke (Synanthedon myopaeformis Borkhausen) elleni védekezés beillesztése az alma integrált védelmébe. Növényvédelem 31, 197-203.

[12] Ilovai, Z., Szabó, P. (1985), Az almafaszitkár (Synanthedon myopaeformis Borkh.) károsításának sajátosságai nagyüzemi almásokban. Növényvédelem, 156-162.

[13] Ateyyat, M. A., Al-Antary, T. M. (2006), Management and within-tree spatial distribution of the small red-belted clearwing borer, Synanthedon myopaeformis (Borkhausen) (Lepidoptera: Sesiidae) infesting dwarfing apple orchards in southern Jordan. Journal of the Entomological Society of British Columbia 103, 11-17.

[14] Balázs K., Le Duc, Khanh (1992), „Lippay János” Tudományos Ülésszak, KÉE Kiadványa, Kertészet-Növényvédelem Szekció, 455-459.

[15] Jenser, G. (1974), Gyümölcsfák védelme. Mezőgazdasági Kiadó, Budapest.

[16] Rencher, Alvin C. (2002), Methods of multivariate analysis. Second Edition. A John Wiley \& Sons, Inc. Publication.

[17] Sváb, J. (1973), Biometriai módszerek a kutatásban. Mezőgazdasági Kiadó, Budapest. 
[18] Le Duc, Khanh, Balázs, K., Mészáros, Z. (1994), Tavaszi védekezési kísérletek eredményei az üvegszárnyú almafalepke (Synanthedon myopaeformis Borkh.) ellen. Növényvédelem 30(5), 219-224.

[19] Mikulás, J. (2012), Az üvegszárnyú almafapille. Kertészet és Szölészet 61(3), 14-15.

[20] Kruhmaleva, L. I. (1967), Borba szo szteklanyicej jáblonoj putyej bülová babocsek na brodjáscsuju fruktovuju szmesz. Volvograd. 